\title{
Hill Districts of Bangladesh Experiences in Development
}

Report of the National Workshop held in Rangamati, Bangladesh January 23-25, 1995

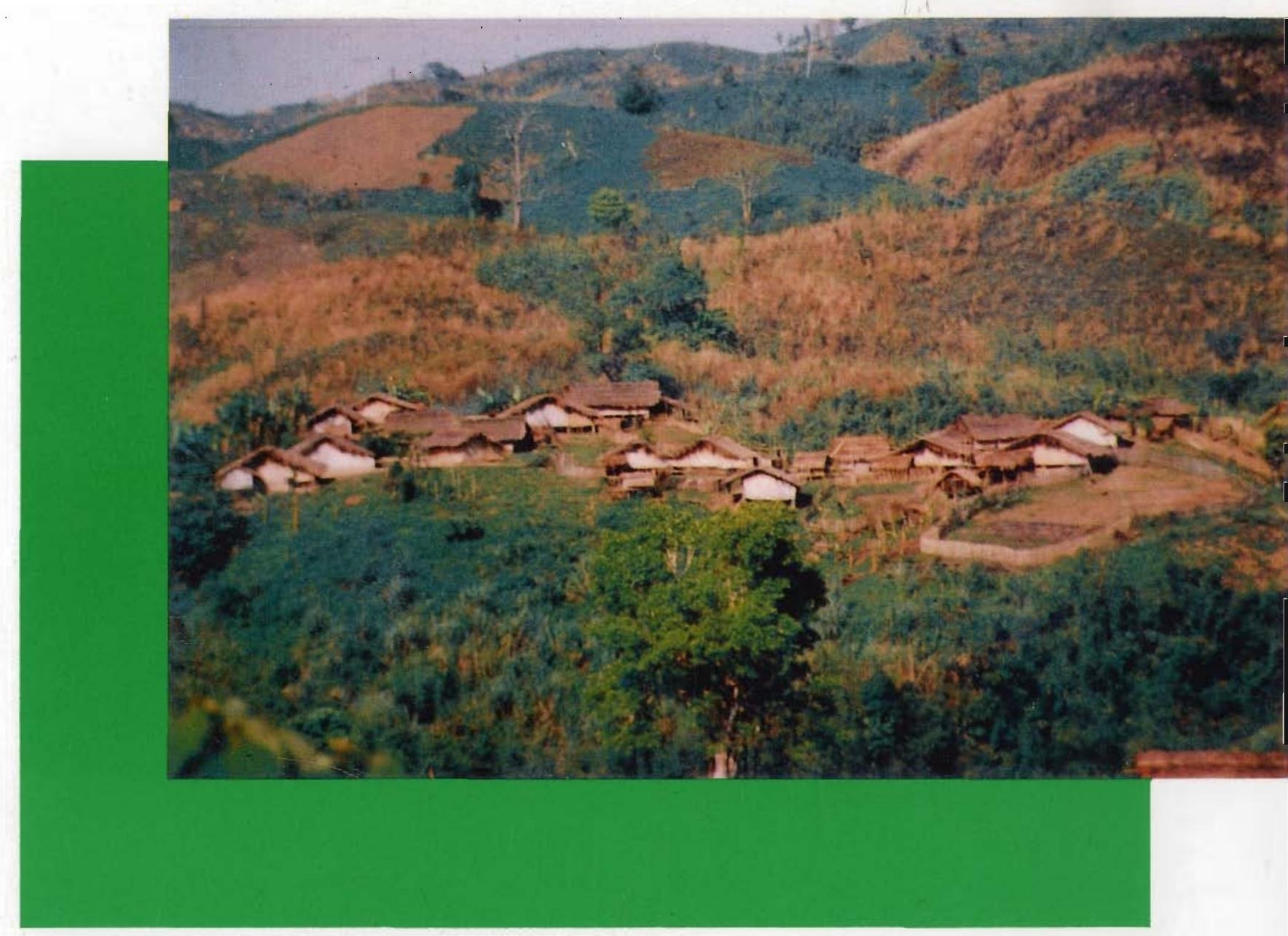

Jointly Organised by

The Special Affairs' Division and.

Chittagong Hill Tracts' Development Board (CHTDB), Government of the People's Republic of Bangladesh, and 
Copyright (C) 1995

International Centre for Integrated Mountain Development

All rights reserved

Cover Photograph: A hill tribe village in the Chittagong Hill Tracts

Published by

International Centre for Integrated Mountain Development

G.P.O. Box 3226,

Kathmandu, Nepal

The views and interpretations in this paper are those of the author(s). They are not attributable to the International Centre for Integrated Mountain Development (ICIMOD) and do not imply the expression of any opinion concerning the legal status of any country, territory, city or area of its authorities, or concerning the delimitation of its frontiers or boundaries. 


\title{
Hill Districts of Bangladesh Experiences in Development
}

\author{
Report of the National Workshop \\ held in Rangamati, Bangladesh \\ January 23 - 25, 1995
}

\author{
Jointly Organised by \\ The Special Afffairs Division and.
}

Chittagong Hill Jracts' Development Board (C HJDDB),

Government of the Deople's Republic of Bangladesh,

and

International Centre for Integrated Mountain Development 


\title{
Foreword
}

The National Workshop on the 'Hill Districts of Bangladesh: Experiences in Development' was the first of its kind ever organised in the Chittagong Hill Tracts (CHT). The Chittagong Hill Tracts' Development Board (CHTDB), The Special Affairs' Division (SAD) of the Prime Minister's Office (PMO), Bangladesh Institute of Development Studies (BIDS), and the Mountain Farming Systems' Programme of ICIMOD put in months of planning and related efforts in order to hold this workshop. When it finally took place, it was indeed a very successful meeting.

First, the meeting brought together many participants, representing at least 25 different organisations - mainly national ones, working in the Chittagong Hill Tracts. Second, the workshop for the first time made a comprehensive review of development activities, identified critical areas of change and problems, and also made some recommendations regarding future priorities. Third, it brought together the existing database on the Chittagong Hill Tracts, providing an excellent basis for future research work. The opportunity to learn from each other in sharing experiences and avoiding duplication was seen as the most valuable achievement of the workshop.

The Chittagong Hill Tracts' Development Board continues to play an important role in promoting integrated development of the Chittagong Hill Tracts with its numerous intersectoral programme activities. ICIMOD, jointly with the Chittagong Hill Tracts' Development Board and others, is also helping to improve the capacity for applications for Geographical Information Systems (GIS), testing of Sloping Agricultural Land Technology (SALT), and on-farm demonstration of Appropriate Technologies for Soil Conserving Farming Systems (ATSCFS), in addition to providing support to professionals in different training programmes. The Workshop has very clearly helped us to assess our efforts as well as to define future priorities. It has been agreed that dialogues such as this should become a regular part of the efforts to promote sustainable development in the Chittagong Hill Tracts.

I would like to thank Major General M. Azizur Rahman, Chairman of the Chittagong Hill Tracts' Development Board, and Dr. Fazlul Hassan Yusuf, Secretary, Special Affairs' Division, for their keen interest in and co-sponsorship of this Workshop and their contributions to the workshop, including their comments on an earlier draft of this report.

ICIMOD is looking forward to promoting follow-up activities that will improve the quality of life of the people and the condition of the environment in the Chittagong Hill Tracts.

\author{
Egbert Pelinck \\ Director General \\ ICIMOD
}




\section{Contents}

Chapter 1 Introduction to the Workshop

Chapter 2 Inauguration of the Workshop

Chapter 3 Summary of Working Sessions

Chapter 4 Conclusions and Recommendations

Annex $1 \quad$ Workshop Programme

Annex $2 \quad$ List of Participants

Abbreviations 